\title{
THE ROLES OF GLASS BLOCK APERTURES IN NATURAL LIGHT DISTRIBUTION FOR THE PRODUCTION ACTIVITY OF CV EVERGREEN BUANA PRIMA SANDANG
}

\author{
${ }^{1}$ Henry Priyadi. ${ }^{2}$ Ir. Mira Dewi Pangestu, M.T. \\ ${ }^{1}$ Student in the Bachelor's (S-1) Study Program in Architecture at \\ Parahyangan Catholic University \\ ${ }^{2}$ Senior lecturer in the Bachelor's (S-1) Study Program in Architecture at \\ Parahyangan Catholic University
}

\begin{abstract}
A factory within the industrial field is both productive and commercial, with profit as its main orientation of activity. One of the efforts to minimize production cost in a factory is electricity saving through optimizing the utilization of natural lightning as a substitute for the use of lamplight. The lighting design in a factory area of production has to concur with specific activities conducted. The level of illumination and sufficient illumination comfort may improve both workers' eyesight and concentration. Glass blocks form one of the commonly chosen materials to be applied as natural light apertures. From an economic point of view, glass block material has an edge in terms of low production cost and maintenance. CV. Evergreen Buana Prima Sandang, as children's clothing factory utilizes natural lighting through glass block apertures, applied to the entire production area and all production stages from beginning to end. Based on theoretical study, they cannot be used to optimize natural lighting in a room, because there is no control over the direction and quality of incoming light. As a host of different activities, the factory's production area requires a differing quantity of lighting. The research was conducted with the descriptive method and the quantitative approach, starting from initial observation of the study object, the medium of interviews and study of the relevant background literature derived from numerous sources. This was followed by direct measurement in the field as well as design simulation of natural lighting. In the analytical process, the influence of conditions around the spot on the intensity of the light source is described along with the role of glass-block apertures in fulfilling the requirement of light intensity illuminating work space, the influence of types and properties of glass blocks, as well as the influence of position and dimension of the apertures on natural light distribution covering each area of production.
\end{abstract}

Keywords: glass block, natural light, production area, children's clothing company

\section{PERANAN BUKAAN GLASS BLOCK DALAM MENDISTRIBUSIKAN CAHAYA ALAMI UNTUK KEGIATAN PRODUKSI PABRIK CV EVERGREEN BUANA PRIMA SANDANG}

\author{
${ }^{1}$ Henry Priyadi. ${ }^{2}$ Ir. Mira Dewi Pangestu, M.T. \\ ${ }^{1}$ Mahasiswa S1 Program Studi Arsitektur Universitas Katolik Parahyangan. \\ ${ }^{2}$ Dosen Pembimbing S1 Program Studi Arsitektur Universitas Katolik Parahyangan.
}

${ }^{1}$ Corresponding Author: pius.henry@hotmail.com 


\begin{abstract}
Abstrak- Pabrik dalam bidang industri bersifat produktif dan komersial, dengan keuntungan sebagai orientasi utama kegiatan. Salah satu upaya untuk menekan biaya operasional produksi pada pabrik adalah penghematan energi listrik melalui optimalisasi pemanfaatan pencahayaan alami sebagai substitusi terhadap penggunaan lampu. Desain pencahayaan pada area produksi pabrik harus sesuai dengan jenis kegiatan spesifik yang dilakukan. Tingkat iluminasi dan kenyamanan pencahayaan yang tercukupi dapat meningkatkan, baik penglihatan maupun konsentrasi pekerja. Glass block merupakan salah satu material yang sering dipilih untuk diaplikasikan sebagai material bukaan cahaya alami. Dari segi ekonomi, material glass block memiliki keunggulan dalam biaya produksi dan pemeliharaan yang cukup rendah. CV. Evergreen Buana Prima Sandang, sebagai pabrik pakaian anak memanfaatkan pencahayaan alami melalui bukaan glass block, yang diaplikasikan pada keseluruhan area produksi, dari tahap awal hingga tahap akhir. Berdasarkan kajian teori, material glass block tidak dapat digunakan untuk mengoptimalisasi pencahayaan alami dalam ruang, karena tidak memiliki kontrol terhadap arah dan kualitas cahaya yang masuk. Area produksi pabrik mewadahi aktivitas yang beragam, membutuhkan kuantitas pencahayaan yang berbeda-beda. Dengan metode deskriptif dan pendekatan kuantitatif, diawali dengan observasi awal objek studi, wawancara, dan studi literatur dari berbagai sumber. Dilanjutkan dengan pengukuran langsung di lapangan, serta simulasi desain pencahayaan alami. Dalam proses analisis, digambarkan pengaruh kondisi sekitar tapak terhadap intensitas sumber cahaya, peran lubang cahaya glass block dalam memenuhi kebutuhan intensitas cahaya pada bidang kerja, pengaruh jenis dan sifat material glass block, serta pengaruh posisi dan dimensi bukaan terhadap distribusi cahaya alami ke masing-masing bidang kerja area produksi.
\end{abstract}

Kata-kata kunci: glass block, cahaya alami, area produksi, pabrik pakaian anak

\title{
1 PENDAHULUAN
}

Fungsi bangunan pabrik dalam bidang industri bersifat produktif dan komersial, dengan keuntungan sebagai orientasi utama kegiatan. Dalam merencanakan kegiatan dalam pabrik perlu diperhitungkan faktor biaya produksi yang dibagi menjadi biaya operasional, pemeliharaan (maintenance) dan keamanaan. Salah satu upaya untuk menekan biaya operasional produksi pada pabrik adalah penghematan energi listrik melalui optimalisasi pemanfaatan pencahayaan alami sebagai substitusi terhadap penggunaan lampu.

Hasil kajian Hawthrone Plant of Western Electric Company, Inc, menyatakan bahwa semakin baik kualitas pencahayaan dalam mendukung kegiatan pabrik, produktivitas kerja akan semakin meningkat. Desain pencahayaan pada area produksi pabrik harus sesuai dengan jenis kegiatan spesifik yang dilakukan. Tingkat iluminasi dan kenyamanan pencahayaan yang tercukupi dapat meningkatkan baik penglihatan maupun konsentrasi pekerja.

Glass block merupakan salah satu material yang sering dipilih untuk diaplikasikan sebagai materal bukaan cahaya alami. Selain memiliki tekstur dan warna yang beragam untuk menghasilkan nilai estetis pada ruang, glass block juga memiliki keunggulan untuk mengurangi kalor dan bising ke dalam ruang. Dari segi ekonomi dalam upaya penghematan biaya konstruksi dan operasional bangunan, material glass block pada umumnya dipilih sebagai material bukaan karena memiliki keunggulan dari aspek biaya produksi dan pemeliharaan yang cukup rendah. Konstruksi glass block juga cenderung cepat karena sifatnya yang modular.

CV Evergeen Buana Prima Sandang sebagai pabrik pakaian anak dipilih sebagai objek studi yang mewadahi berbagai tahap kegiatan produksi. Cahaya alami dimasukkan ke dalam ruang produksi melalui bukaan glass block yang terletak pada bagian utara dan selatan bangunan, dengan posisi jendela sedang dan tinggi, sebagai penerangan umum sekaligus penerangan pada bidang kerja. Desain bukaan cahaya pada setiap tahap area produksi juga diseragamkan untuk mempercepat waktu konstruksi bangunan. Pencahayaan alami dengan material bukaan glass block 
diaplikasikan sebagai upaya penghematan biaya operasional dan konstruksi pabrik melalui keunggulan material untuk menekan biaya produksi dan konstruksi bukaan cahaya.

Objek studi direncanakan oleh sang arsitek dengan menggunakan pencahayaan alami melalui bukaan glass block, yang diaplikasikan dari tahap awal hingga akhir area produksi. Namun berdasarkan kajian teori awal menurut Lechner (2015), material glass block tidak dapat digunakan untuk mengoptimalisasi pencahayaan alami dalam ruang karena tidak memiliki kontrol terhadap arah dan kualitas cahaya yang masuk.

Area produksi pabrik juga mewadahi aktivitas yang beragam mulai dari pemotongan, jahit, gunting benang, gosok, quality control, hingga packing. Kebutuhan kuat pencahayaan pada masing-masing aktivitas juga berbeda sesuai dengan standar yang direkomendasikan

(Neufert, 2000). Namun berdasakan observasi awal ditemukan bahwa aplikasi desain bukaan cenderung diseragamkan dan tidak disesuaikan dengan variasi kegiatan pada masing-masing tahapan produksi.

Berdasarkan hal di atas, maka penelitian ini dilakukan dengan tujuan untuk mengetahui dan membandingkan hasil kajian teori awal dengan distribusi cahaya alami pada bidang kerja. Dalam penelitian ini akan digambarkan pengaruh kondisi sekitar tapak terhadap intensitas sumber cahaya, peran lubang cahaya glass block dalam memenuhi kebutuhan intensitas cahaya pada bidang kerja, pengaruh jenis dan sifat material glass block, serta pengaruh posisi dan dimensi bukaan terhadap distribusi cahaya alami.

\section{KAJIAN TEORI}

Standar pencahayaan pada penelitian mengacu pada standar internasional dari Data Arsitek, dikaitkan dengan standar nasional dari Kepmenkes No. 1045 Tahun 2002, sebagai dasar rekomendasi kebutuhan kuat pencaahayaaan sesuai dengan masing-masing jenis kegiatan produksi dalam pabrik.

Faktor-faktor lubang cahaya yang mempengaruhi intensitas cahaya yang masuk ke dalam ruang dibagi menjadi dimensi, posisi, dan material bukaan. Menurut Karlen (2006), pencahayaan dinding/sidelighting merupakan bentuk pemanfaatan bukaan vertikal berupa jendela untuk memasukkan cahaya ke dalam ruangan. Sidelighting cenderung mengakibatkan silau dari intensitas cahaya matahari yang tinggi dan tergantung dari permukaan bidang pantul pada ruangan. Berdasarkan Kepmenkes No. 1045 Tahun 2003, untuk memenuhi kesehatan lingkungan kerja industry, terdapat persyaratan mengenai luas jendela sidelighting, baik dalam bentuk kisi-kisi maupun material kaca, yang harus dipenuhi sebesar 1/6 kali luas lantai area kerja.

Menurut Kingsbury (1957), glass block didesain dan umum digunakan sebagai dinding bangunan yang dapat membelikkan arah cahaya yang ditransmisikan melalui bukaan. Glass block berperan sebagai diffuser pada sidelighting dengan mendistribusikan cahaya secara menyebar ke segala arah dan meningkatkan porsi cahaya yang masuk ke ruang dalam di atas bidang horizontal mata manusia. 


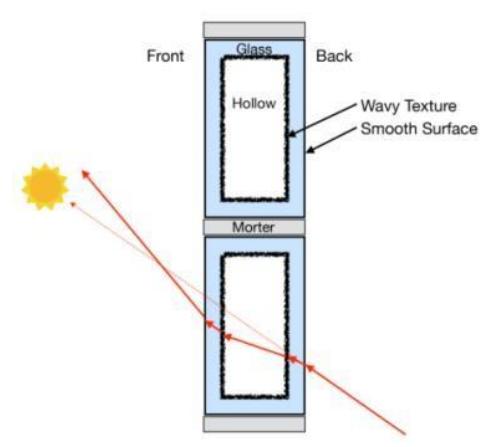

Figur 1. Komponen Penyusun Glass Block (Sumber: McNeil, 2015)

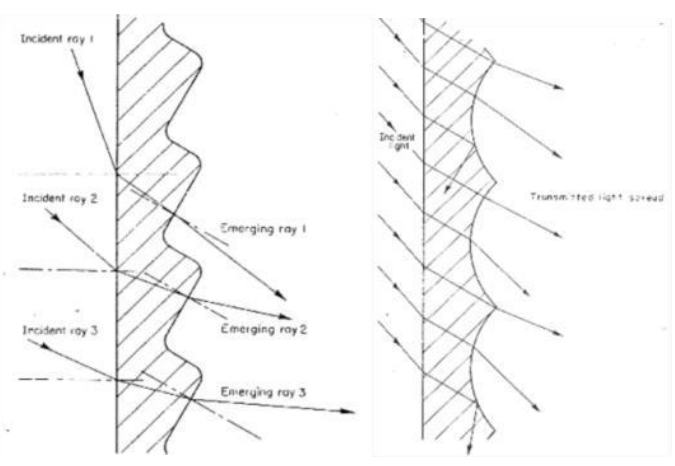

Figur 2. Refracting glass dan ribbed glass untuk kontrol cahaya alami

(Sumber: Phillips, 1964)

Material glass block tersusun oleh dua buah kaca prismatik dengan tekstur permukaan luar yang halus dan tekstur permukaan dalam yang kasar. Kedua kaca prismatik tersebut disusun dengan jarak sesuai dengan dimensi yang diinginkan sehingga menghasilkan rongga kosong diantaranya. Masing-masing blok kaca direkatkan dengan adukan semen untuk menghasilkan jendela glass block secara utuh.
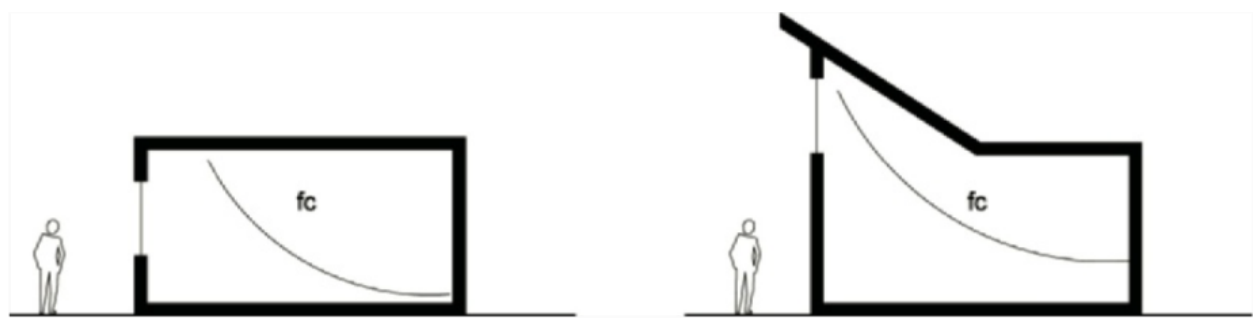

Figur 3. Penetrasi Cahaya Alami Pada Bukaan Sedang dan Tinggi

(Sumber: Lechner, 2015)

Menurut Lam (1992), terdapat tiga macam posisi bukaan pada tipe bukaan dinding atau sidelight, yaitu jendela rendah, sedang, dan tinggi. Posisi bukaan jendela sedang terletak pada ketinggian garis pandang mata manusia. Cahaya alami yang masuk melalui jendela sedang didistribusikan ke bidang permukaan yang terletak dekat dengan bukaan, sehingga intensitas cahaya di sekitar bukaan cenderung lebih tinggi. Penetrasi cahaya melalui jendela sedang cenderung rendah sehingga kurang efektif untuk memasukkan cahaya jauh ke dalam ruang.

Posisi bukaan jendela tinggi terletak di atas garis pandang mata manusia. Jendela tinggi memiliki keunggulan yaitu dapat memasukkan cahaya alami jauh ke dalam ruangan, baik yang berasal dari cahaya satu arah maupun cahaya yang dibiaskan, sehingga cahaya dapat menerangi ruang dan bidang kerja horizontal secara merata. Semakin tinggi posisi bukaan, penetrasi cahaya akan semakin jauh ke dalam ruang. Namun jendela tinggi memiliki kekurangan yaitu terdapat area yang kurang mendapatkan cahaya alami pada bidang sekeliling bukaan dan tidak memberikan view kepada pengguna bangunan. 
Glass block tersusun dari komponen prisma kaca sebagai media yang mempengaruhi arah cahaya yang masuk ke dalam ruangan. Berdasarkan prinsip perjalanan cahaya, cahaya yang melewati dua batas media dapat mengalami peristiwa pembiasan (refraksi), pemantulan (refleksi), penyerapan (absorbsi), dan penerusan (transmisi).

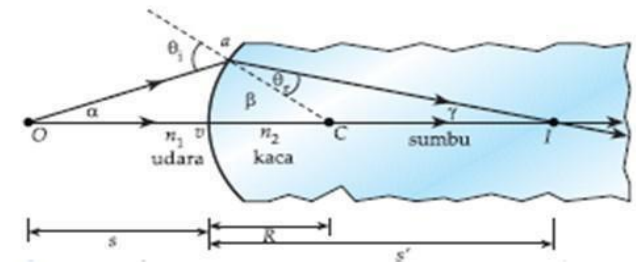

Figur 4. Berkas Cahaya Melewati Permukaan Cembung Sumber: Kumorowati, 2015

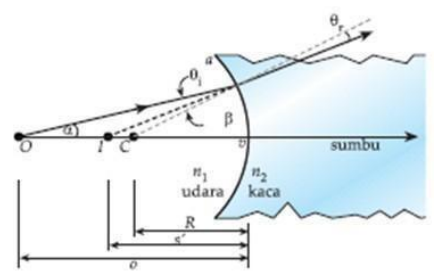

Figur 5. Berkas Cahaya Melewati Permukaan Cekung Sumber: Kumorowati, 2015

Pada transmisi cahaya dapat terjadi peristiwa pembiasan cahaya atau refraksi. Refraksi cahaya merupakan peristiwa pembelokkan arah cahaya yang terjadi saat cahaya melewati dua medium dengan tingkat kerapatan yang berbeda. Pembelokkan cahaya juga dapat terjadi pada saat cahaya mengenai bidang permukaan bidang lengkung/sferis.

Komponen prisma kaca pada glass block dapat dikategorikan sebagai bidang lengkung, yakni kaca yang memiliki salah satu atau kedua sisi permukaan bidang lengkung. Suatu bidang lengkung tembus cahaya dapat membiaskan cahaya yang mengenai permukaan bidang tersebut sesuai dengan hukum Snellius.

\section{HASIL PENGAMATAN DAN ANALISIS}

\subsection{LINGKUNGAN SEKITAR BANGUNAN}

Bagian utara tapak masih merupakan tanah kosong, sehingga masuknya cahaya alami belum terlahang oleh bangunan di luar tapak. Namun terdapat dinding pembatas yang posisinya dekat dengan bukaan sehingga menjadi hambatan bagi penetrasi cahaya alami pada bagian utara. Pada bagian selatan bangunan, terdapat jalan sirkulasi yang cenderung kosong. Hal ini menjadi potensi bagi pencahayaan alami karena penetrasi cahaya alami tidak terhalang oleh elemen lain.

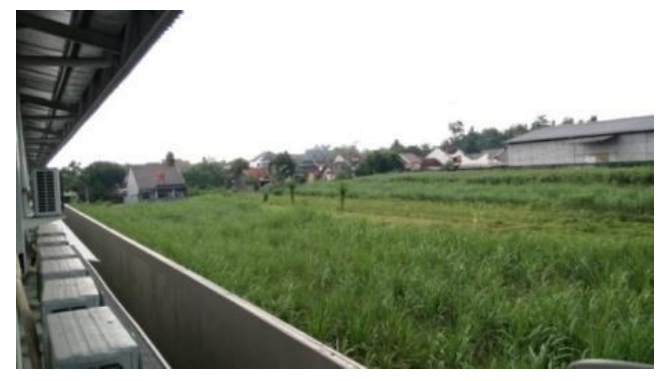

Figur 6. Kondisi Lingkungan Bagian Utara

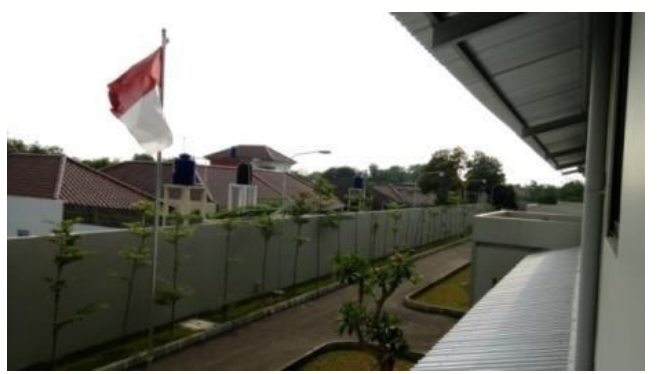

Figur 7. Kondisi Lingkungan Bagian Selatan 


\subsection{LOKASI TAPAK DAN ORIENTASI BANGUNAN}

Tapak berlokasi pada koordinat $7^{\circ} 46^{\prime}$ lintang selatan dan $110^{\circ} 27^{\prime}$ bujur timur. Berdasarkar figur 6, koordinat bangunan terletak di bawah jalur pergerakan matahari. Hal ini menunjukkan bukaan bagian utara bangunan mendapatkan pemaparan sinar matahari lebih banyak daripada sisi bukaan bagian selatan pada akhir bulan September hingga awal bulan Oktober 2016.

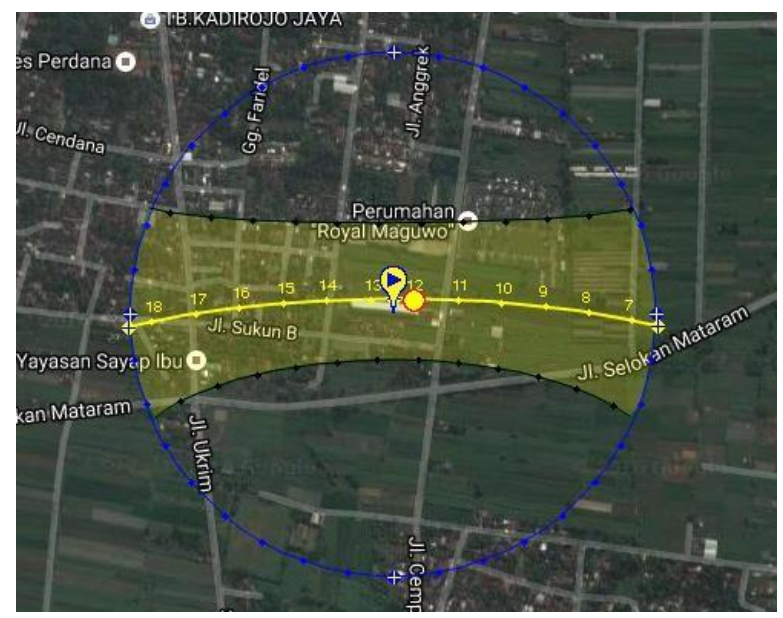

Figur 8. Pergerakan Matahari September 2016

(Sumber: www.sunearthtools.com)

Orientasi bukaan mengarah ke utara dan selatan. Hal ini menjadi potensi bagi cahaya alami untuk masuk secara konstan ke dalam bangunan. Namun orientasi bangunan yang cenderung miring $5^{\circ}$ menghasilkan pemaparan cahaya matahari yang sedikit lebih banyak ke fasad utara pada pagi hari, dan ke fasad selatan pada sore hari.

\subsection{Peran Jenis dan Sifat Material Glass Block}

Glass block memiliki struktur pengisi yang terdiri dari 2 bidang kaca yang dibatasi oleh ruang kosong. Setiap modul glass block direkatkan dengan nat dengan ketebalan $1 \mathrm{~cm}$ dan disusun hingga membentuk dimensi lubang cahaya. Komponen kaca prismatik berfungsi membentuk tekstur sekaligus mempengaruhi arah cahaya yang masuk ke dalam ruang. Berdasarkan kajian teori mengenai perjalanan cahaya dan kondisi eksisting glass block yang dipasang dengan pola tekstur horizontal, arah cahaya mengalami refraksi saat melewati modul glass block. Refraksi pada glass block dapat terjadi baik secara vertikal (potongan) maupun horizontal (denah).

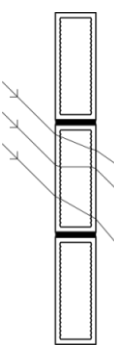

Figur 9. Distribusi Cahaya Pada Glass block Secara Vertikal

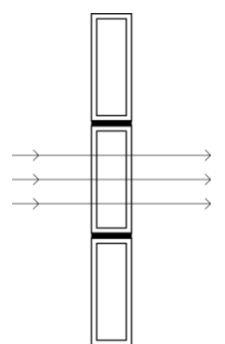

Figur 10. Distribusi Cahaya Pada Glass block Secara Horizontal 
Dari penjabaran distribusi cahaya melalui glass block secara horizontal dan vertikal, diketahui peran lubang cahaya glass block dalam menghasilkan cahaya yang bersifat menyebar secara vertikal, sehingga memperkuat penetrasi cahaya lebih jauh ke dalam ruang dan memperlebar berkas distribusi cahaya pada bidang permukaan. Namun secara horizontal, cahaya ditransmisikan secara spekular, sehingga intensitas cahaya lebih terarah ke bidang kerja yang terletak dekat dengan lubang cahaya.

\subsection{Peran Dimensi dan Posisi Lubang Cahaya}

Dalam memenuhi kebutuhan pencahayaan pada area industri, dimensi bukaan direkomendasikan berdasarkankan Kepmenkes No. 1045 Tahun 2002, untuk memenuhi 1/6 dari luas lantai ruang.

Tabel 1. Perhitungan Luas Bukaan

\begin{tabular}{|l|l|}
\hline Luas total bukaan yang dianjurkan & $=1 / 6 \times$ luas lantai area produksi \\
& $=1 / 6 \times(10 \mathrm{~m} \times 81 \mathrm{~m})$ \\
& $=1 / 6 \times 810 \mathrm{~m}^{2}=135 \mathrm{~m}^{2}$ \\
\hline Luas bukaan eksisting & $=$ jumlah bukaan $\times$ dimensi bukaan \\
& $=(47+46) \times(1.4 \mathrm{~m} \times 0.6 \mathrm{~m})$ \\
& $=93 \times 0.84 \mathrm{~m}^{2}=78.12 \mathrm{~m}^{2}$ \\
\hline \% terhadap rekomendasi 1/6 luas & $=\mathbf{5 7 . 8 7} \%$ \\
\hline Dimensi bukaan yang harus dipenuhi & $=$ luas total $:$ jumlah bukaan \\
& $=135 \mathrm{~m}^{2}: 93$ \\
& $=\mathbf{1 . 4 5} \mathbf{~ m}^{\mathbf{2}}$ \\
&
\end{tabular}

Berdasarkan perhitungan luas bukaan pada tabel 1, luas bukaan pada area produksi terhitung hanya memenuhi $57.87 \%$ kebutuhan dimensi bukaan yang dianjurkan, sehingga faktor dimensi bukaan menjadi salah satu penyebab kurangnya intensitas cahaya pada ruang.

Untuk memenuhi standar tersebut, luas total bukaan yang harus dipenuhi pada area produksi sebesar 135 meter persegi. Luas tersebut diterapkan pada seluruh bukaan sama besar, sehingga setiap bukaan harus memiliki luas minimal sebesar 1.45 meter persegi. Bila dikaitkan dengan modul glass block $20 \mathrm{~cm}$ x $20 \mathrm{~cm}$, salah satu opsi dimensi bukaan minimal yang harus dipenuhi adalah sebesar $120 \mathrm{~cm}$ lebar x $140 \mathrm{~cm}$ tinggi bukaan.

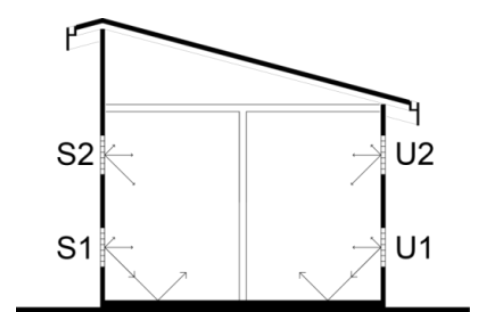

Figur 11. Potongan Arah Berkas Cahaya Melalui Jendela Sedang Utara dan Selatan 
Faktor lain yang mempengaruhi intensitas cahaya yang masuk ke dalam bangunan adalah posisi bukaan. Pada objek studi, posisi bukaan jendela sedang pada berperan sebagai sumber cahaya terbesar bagi bidang kerja yang terletak dekat dengan dinding utara dan selatan bangunan pada setiap area tahap produksi. Namun jendela sedang tidak dapat menjangkau dan memenuhi bidang kerja yang terletak di tengah lebar bangunan karena berkas penyebarannya yang terbatas dan terpusat di sekitar bukaan. Cahaya yang masuk melalui jendela sedang juga tidak dapat dipantulkan ke bidang plafon untuk memperkuat penetrasi cahaya jauh ke dalam ruangan karena ketinggian plafon yang sangat jauh dari posisi lubang cahaya.
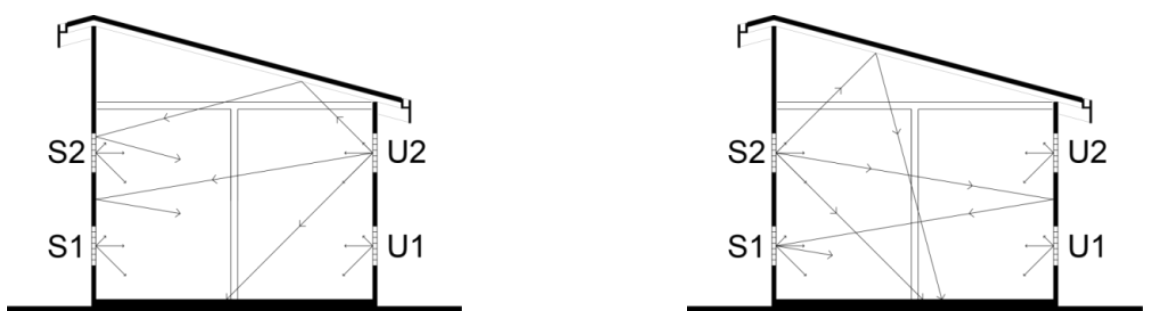

Figur 12. Potongan Arah Berkas Cahaya Melalui Jendela Tinggi Utara dan Selatan

Posisi bukaan jendela tinggi memasukkan cahaya alami jauh ke dalam ruang melalui refleksi material permukaan ruang dalam dan menghasilkan cahaya yang menerangi ruang dan bidang kerja secara horizontal. Sifat penyebaran cahaya yang dihasilkan oleh posisi bukaan jendela tinggi bersifat menyebar secara horizontal. Pada objek studi, intensitas cahaya yang masuk melalui posisi bukaan jendela tinggi berperan sebagai general lighting pada ruangan. Elemen material alumunium pada plafon, dengan tingkat reflektansi material sebesar $70 \%-85 \%$, juga berperan untuk memantulkan cahaya ke dalam ruang dan bidang kerja. Dari penjabaran tersebut, posisi bukaan tinggi lebih efektif digunakan untuk meningkatkan intensitas cahaya secara menyeluruh, dan meneruskan berkas cahaya hingga bidang kerja yang berada di tengah lebar bangunan.

Peran posisi dan dimensi bukaan akan dijabarkan lebih mengerucut pada analisis karakteristik bukaan area potong, obras, gunting benang, dan gosok untuk menunjukkan efektififtas peran masing-masing bukaan pada kegiatan yang berbeda dengan kebutuhan intensitas cahaya dan konfigurasi bidang kerja yang berbeda-beda pula.

\subsection{PENCAHAYAAN AREA POTONG}

Berdasarkan hasil pengukuran langsung di lapangan, dikaitkan dengan standar rekomendasi kebutuhan pencahayaaan sesuai dengan kegiatan, maka diperoleh perbandingan nilai intensitas cahaya pada area potong.
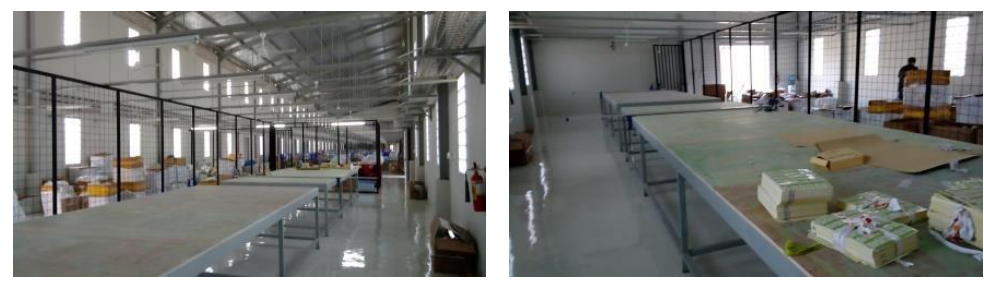

Figur 13. Kondisi Interior Area Potong 
Tabel 2. Perbandingan Hasil Pengukuran Intensitas Cahaya Area Potong

\begin{tabular}{|c|c|c|c|}
\hline \multirow{2}{*}{ Titik Ukur } & \multicolumn{3}{|c|}{ Intensitas Cahaya (lux) } \\
\cline { 2 - 4 } & Pukul 09.00 & Pukul 12.30 & Pukul 15.30 \\
\hline A1 & 105.8 & 84.6 & 85.4 \\
\hline A2 & 105.3 & 103.5 & 82.7 \\
\hline A3 & 103.0 & 92.1 & 72.7 \\
\hline A4 & 94.1 & 99.1 & 81.5 \\
\hline A5 & 102.7 & 94.1 & 104.3 \\
\hline A6 & 108 & 108.8 & 88.6 \\
\hline A7 & 121.9 & 115.0 & 85.2 \\
\hline A8 & 104.6 & 115.1 & 85.3 \\
\hline Nilai Median & 105.0 & 101.3 & $8.53 \%$ \\
\hline \% Terhadap Standar 1000 lux & $10.50 \%$ & $10.13 \%$ & \\
\hline
\end{tabular}

Pada area potong, intensitas cahaya hanya memenuhi $8 \%-10 \%$ dari kebutuhan intensitas pencahayaan untuk kegiatan pemotongan sebesar 1000 lux. Konfigurasi meja potong terletak lebih dekat dengan dinding selatan bangunan sehingga cahaya pada bidang kerja banyak dipengaruhi oleh lubang cahaya pada bidang dinding selatan.

Tabel 3. Perbandingan Hasil Simulasi Kondisi Eksisting dan Kondisi Ideal Area Potong

\begin{tabular}{|c|c|c|}
\hline \multicolumn{2}{|c|}{} & \\
\hline & & \\
\hline
\end{tabular}


Dari tabel 3, intensitas cahaya mengalami peningkatan inensitas cahaya hanya sebesar $9.03 \%$, setelah dipenuhi standar minimal dimensi bukaan oleh Kepmenkes No. 1045 Tahun 2002, sebesar 1/6 dari luas lantai. Namun intensitas cahaya yang dihasilkan pada kondisi ideal tersebut masih sangat kurang dan hanya memenuhi $17.39 \%$ dari standar minimal yang dianjurkan sebesar 1000 lux.

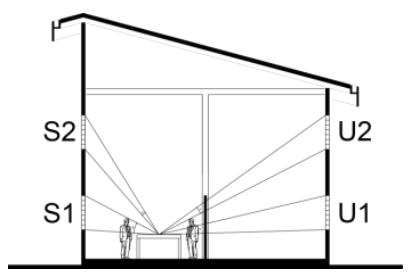

Figur 14. Distribusi Intensitas Cahaya Oleh Lubang Cahaya Area Potong

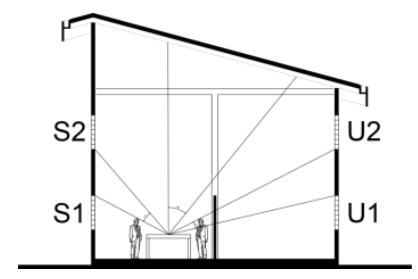

Figur 15. Distribusi Intensitas Cahaya Oleh Bidang Dinding dan Plafon Area Potong

Posisi jendela sedang merupakan sumber intensitas tertinggi pada meja potong. Namun sudut distribusi intensitas cahaya oleh jendela sedang S1 dan U1 terhalang oleh pengguna yang membelakangi bukaan, sehingga kedua posisi bukaan jendela sedang tidak efektif digunakan sebagai pencahayaan area potong. Posisi pengguna terhadap lubang cahaya berpotensi menghasilkan gangguan silau atau kontras yang berlebih karena timbul bayang-bayang pengguna pada bidang kerja.

Meskipun intensitas cahaya yang dihasilkan oleh jendela tinggi bernilai lebih kecil, jendela tinggi lebih baik untuk memasukkan cahaya ke bidang kerja karena tidak terhalang oleh posisi pengguna. Sebagian berkas cahaya yang masuk melalui jendela tinggi juga dipantulkan terlebih dahulu ke bidang dinding dan plafon sehingga kedua bidang permukaan tersebut berperan sebagai sumber cahaya tambahan ke bidang kerja. Dinding selatan dan plafon pada area potong berkontribusi untuk meningkatkan intensitas cahaya pada bidang kerja, sedangkan dinding utara kurang efektif untuk meningkatkan intensitas cahaya pada bidang kerja karena terhalang oleh posisi pengguna.

Dari hasil penjabaran tersebut, lubang cahaya utama sidelighting pada area potong memiliki 2 peran yang berbeda berdasarkan posisi bukaannya. Namun setelah dikaitkan dengan konfigurasi bidang kerja, posisi bukaan jendela sedang tidak dapat digunakan untuk memasukkan cahaya alami ke meja potong secara efektif. Sebaliknya, posisi bukaan jendela tinggi berkontribusi besar untuk meningkatkan intensitas cahaya pada bidang kerja sekaligus membentuk general lighting pada area potong. Intensitas cahaya yang masuk melalui posisi bukaan jendela tinggi masih dapat ditingkatkan potensinya dengan menambah dimensi lubang cahaya atau mengganti material bukaan glass block dengan kaca bening. 


\subsection{PENCAHAYAAN AREA OBRAS}

Berdasarkan hasil pengukuran langsung di lapangan, dikaitkan dengan standar rekomendasi kebutuhan pencahayaaan sesuai kegiatan, diperoleh perbandingan nilai intensitas cahaya pada area obras.
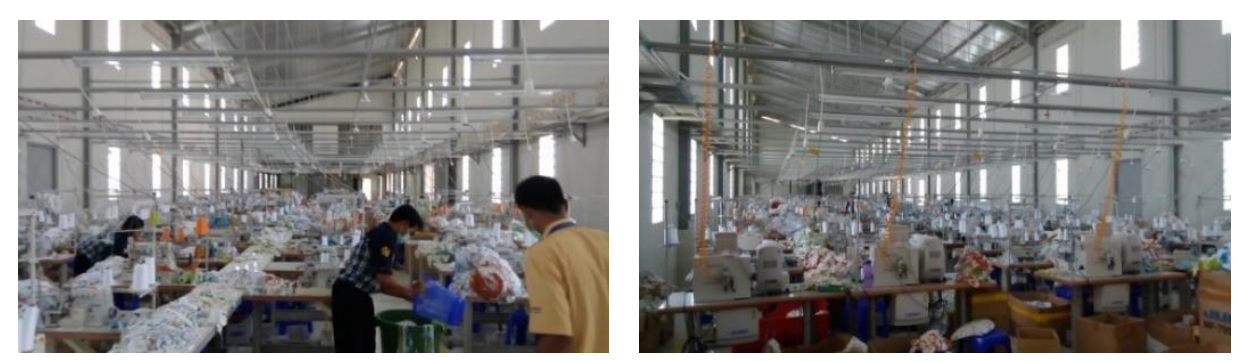

Figur 16. Kondisi Interior Area Obras

Tabel 4. Perbandingan Hasil Pengukuran Intensitas Cahaya Area Obras

\begin{tabular}{|c|c|c|c|}
\hline \multirow{2}{*}{ Titik Ukur } & \multicolumn{3}{|c|}{ Intensitas Cahaya (lux) } \\
\cline { 2 - 4 } & Pukul 09.00 & Pukul 12.30 & Pukul 15.30 \\
\hline B1 & 109.6 & 126 & 60.1 \\
\hline B2 & 104 & 113.6 & 70.2 \\
\hline B3 & 112.8 & 132.6 & 101.2 \\
\hline B4 & 70.4 & 103 & 68.4 \\
\hline B5 & 76 & 109.8 & 75.4 \\
\hline B6 & 90.4 & 101.5 & 70.6 \\
\hline B7 & 107.5 & 116.2 & 70.1 \\
\hline B8 & 95 & 86.3 & 72.6 \\
\hline B9 & 115.8 & 133.1 & 114.8 \\
\hline Nilai Median & 104.0 & 101.5 & 70.6 \\
\hline \% Terhadap Standar 300 lux & $34.67 \%$ & $33.83 \%$ & $23.53 \%$ \\
\hline
\end{tabular}

Pada area obras, intensitas cahaya hanya memenuhi $23 \%$ - 34\% dari kebutuhan intensitas pencahayaan untuk kegiatan rutin dengan mesin obras sebesar 300 lux. Konfigurasi bidang kerja area obras dibagi menjadi 3 baris dekat dengan dinding utara bangunan, di tengah lebar bangunan, dan dekat dengan dinding selatan bangunan.

Tabel 5. Perbandingan Hasil Simulasi Kondisi Eksisting dan Kondisi Ideal Area Obras

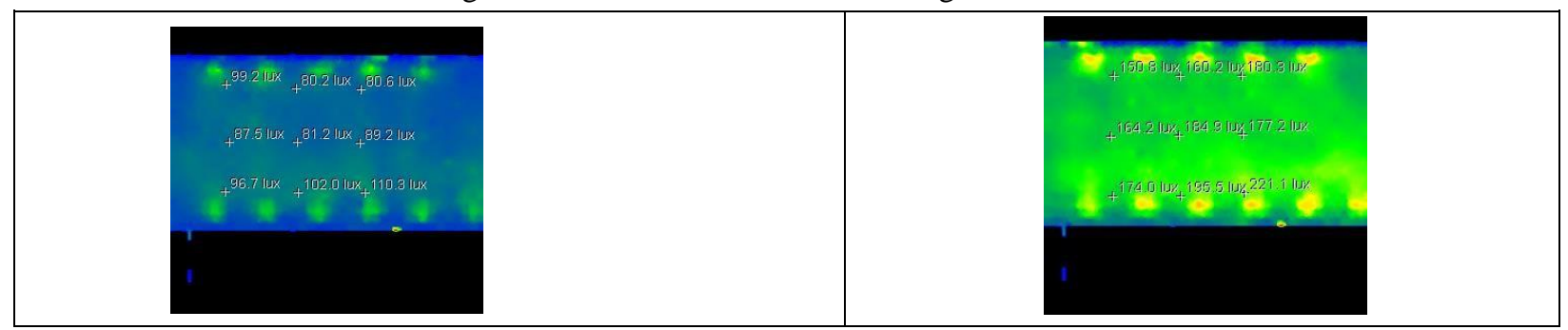




\begin{tabular}{|c|c|c|}
\hline \multirow{2}{*}{ Titik Ukur } & \multicolumn{2}{|c|}{ Intensitas Cahaya (lux) pukul 12.30 } \\
\cline { 2 - 3 } & Kondisi Eksisting & Kondisi A \\
\hline B1 & 99.2 & 150.8 \\
\hline B2 & 80.3 & 160.2 \\
\hline B3 & 80.6 & 180.3 \\
\hline B4 & 87.5 & 164.2 \\
\hline B5 & 81.2 & 184.9 \\
\hline B6 & 89.2 & 177.2 \\
\hline B7 & 96.7 & 174.0 \\
\hline B8 & 102.0 & 195.5 \\
\hline B9 & 110.3 & 221.1 \\
\hline Nilai Median & 89.2 & 177.2 \\
\hline \% Terhadap Standar 300 lux & $29.73 \%$ & $59.07 \%$ \\
\hline
\end{tabular}

Dari tabel 5, intensitas cahaya mengalami peningkatan sebesar $29.3 \%$ kebutuhan intensitas cahaya, setelah dipenuhi standar minimal dimensi bukaan oleh Kepmenkes No. 1045 Tahun 2002, sebesar 1/6 dari luas lantai. Namun intensitas cahaya yang dihasilkan pada kondisi ideal hanya dapat memenuhi kebutuhan pencahayaan pada area obras sebesar 59.07\% dari standar minimal yang direkomendasikan sebesar 300 lux.
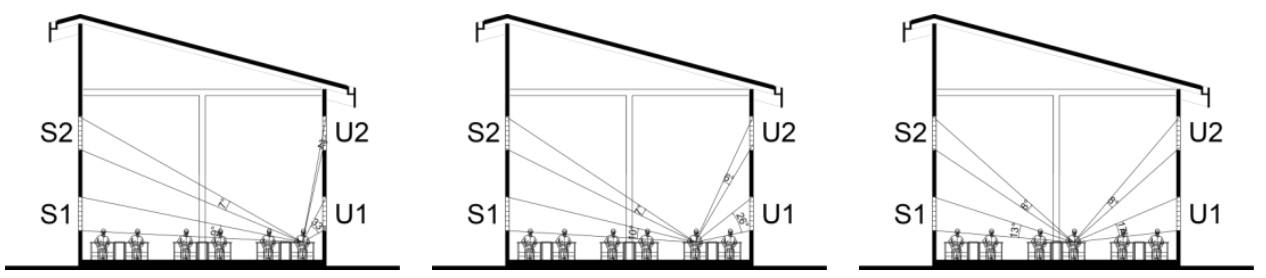

Figur 17. Distribusi Intensitas Cahaya Oleh Lubang Cahaya Area Obras

Posisi pengamat tidak langsung berlawanan dengan arah lubang cahaya sehingga tidak ada berkas cahaya yang terhalang oleh pengamat. Untuk distribusi intensitas cahaya pada meja obras yang terletak dekat dengan dinding, sudut intensitas yang terbentuk dari masing-masing lubang cahaya sebesar $26^{\circ}-33^{\circ}$ pada $\mathrm{U} 1,2^{\circ}-6^{\circ}$ pada $\mathrm{U} 2,9^{\circ}-10^{\circ}$ pada $\mathrm{S} 1$, dan $7^{\circ}$ pada $\mathrm{S} 2$. Sedangkan untuk distribusi intensitas cahaya pada meja obras yang terletak di tengah, sudut intensitas yang terbentuk sebesar $17^{\circ}$ Pada $U 1,8^{\circ}$ pada $U 2,13^{\circ}$ pada $S 1$, dan $8^{\circ}$ pada $S 2$.

Penjabaran tersebut memperkuat hasil analisis bahwa jendela sedang U1 merupakan sumber intensitas tertinggi pada meja obras yang berada di pinggir. Pada posisi meja obras yang berada di tengah, intensitas cahaya dari posisi jendela sedang mengalami penurunan, namun terdapat peningkatan nilai intensitas dari jendela tinggi. Artinya, intensitas cahaya yang masuk melalui jendela tinggi lebih efektif untuk mendukung pencahayaan pada bidang kerja pada bagian tengah, meskipun sudut intensitas yang terbentuk masih rendah. Namun, sebagian berkas cahaya yang masuk melalui jendela tinggi juga dipantulkan terlebih dahulu ke bidang dinding dan plafon 
sehingga kedua bidang permukaan tersebut berperan sebagai sumber cahaya tambahan ke bidang kerja.
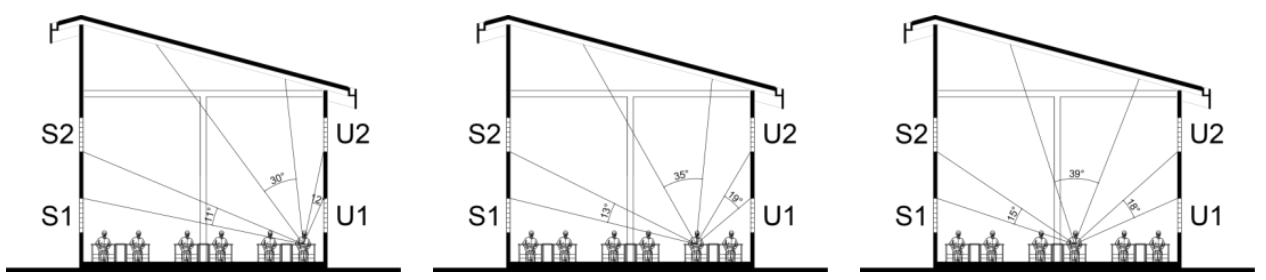

Figur 18. Distribusi Intensitas Cahaya Oleh Bidang Permukaan Area Potong

Berdasarkan penggambaran distribusi intensitas cahaya oleh bidang permukaan, sudut distribusi cahaya yang terbentuk pada bidang kerja bagian tengah sebesar $39^{\circ}$ pada plafon, serta $18^{\circ}$ dan $15^{\circ}$ pada dinding utara dan selatan. Namun semakin pinggir titik bidang kerja, semakin berkurang juga efektifitas refleksi material dalam mendistribusikan cahaya ke bidang kerja. Sudut distribusi intensitas cahaya terhadap bidang kerja yang terletak di pinggir berkurang menjadi $30^{\circ}$ oleh plafon, serta $12^{\circ}$ dan $11^{\circ}$ oleh dinding utara dan selatan.

Dari hasil penjabaran tersebut, masing-masing posisi lubang cahaya utama berkontribusi untuk meningkatkan intensitas cahaya pada bidang kerja. Jendela sedang efektif untuk meningkatkan pencahayaan pada bidang kerja yang terletak di pinggir, sedangkan jendela tinggi dapat meningkatkan intensitas cahaya pada seluruh bidang kerja secara merata, terutama bidang kerja yang terletak di tengah. Cahaya yang masuk melalui jendela tinggi didukung oleh bidang permukaan dinding dan plafon sehingga dapat didistribusikan secara tersebar.

Peningkatan intensitas cahaya dapat dilakukan pada kedua posisi bukaan sesuai dengan kebutuhannya masing-masing. Intensitas cahaya yang masuk melalui posisi bukaan jendela tinggi masih dapat ditingkatkan potensinya dengan opsi menambah dimensi lubang cahaya, mengganti material bukaan glass block dengan kaca bening, atau meningkatkan nilai reflektansi material dinding dan plafon. Sedangkan pada jendela sedang, peningkatan dapat dilakukan dengan opsi menambah dimensi bukaan.

\subsection{PENCAHAYAAN AREA GUNTING BENANG}

Berdasarkan hasil pengukuran langsung di lapangan, dikaitkan dengan standar rekomendasi kebutuhan pencahayaaan sesuai dengan kegiatan, maka diperoleh perbandingan nilai intensitas cahaya pada area gunting benang.
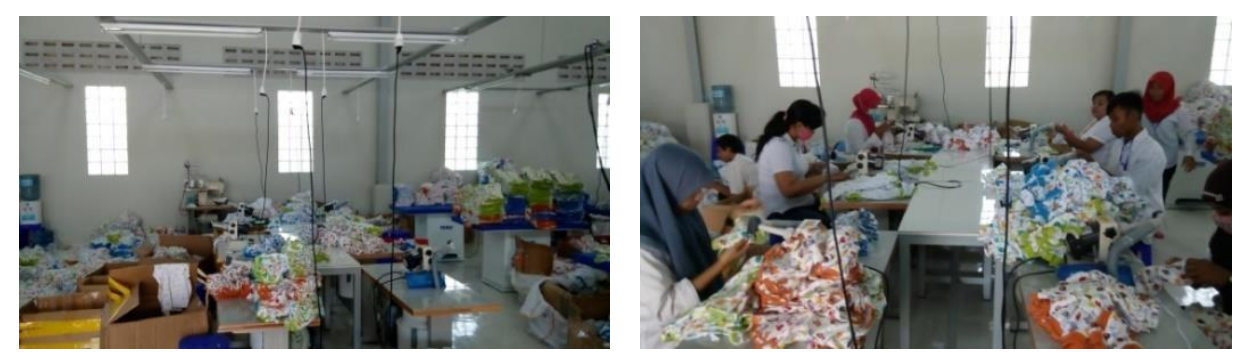

Figur 19. Kondisi Interior Area Gunting Benang 
Tabel 6. Perbandingan Hasil Pengukuran Intensitas Cahaya Area Gunting Benang

\begin{tabular}{|c|c|c|c|}
\hline \multirow{2}{*}{ Titik Ukur } & \multicolumn{3}{|c|}{ Intensitas Cahaya (lux) } \\
\cline { 2 - 4 } & Pukul 09.00 & Pukul 12.30 & Pukul 15.30 \\
\hline C1 & 93.4 & 109.7 & 77.4 \\
\hline C2 & 99.1 & 113 & 81 \\
\hline C3 & 106.2 & 103.2 & 76.5 \\
\hline C4 & 82.8 & 102.5 & 75.1 \\
\hline C5 & 111.4 & 120.2 & 78.7 \\
\hline C6 & 66.8 & 106.8 & 79.20 \\
\hline Nilai Median & 96.25 & 111.35 & $15.84 \%$ \\
\hline \% Terhadap Standar 500 lux & $19.25 \%$ & $22.27 \%$ & \\
\hline
\end{tabular}

Tabel 7. Perbandingan Hasil Simulasi Kondisi Eksisting dan Ideal Area Gunting Benang

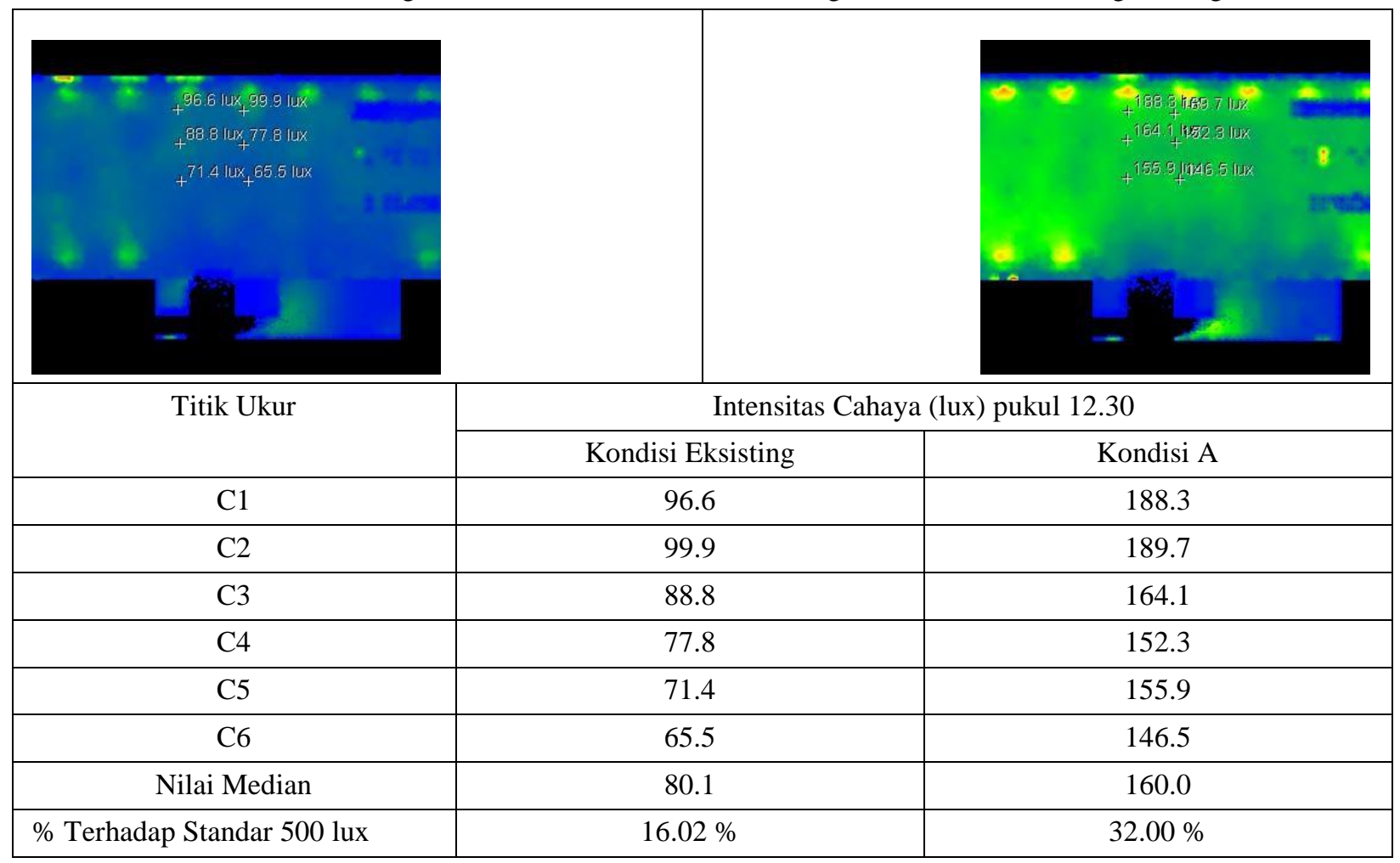

Pada area gunting benang, intensitas cahaya hanya memenuhi 15\% - 22\% dari kebutuhan intensitas pencahayaan untuk kegiatan pemeriksaan dan pengguntingan benang hasil obras sebesar 500 lux.

Konfigurasi bidang kerja area gunting benang terletak pada bagian tengah hingga utara lebar bangunan, sedangkan bagian selatan area gunting benang digunakan sebagai sirkulasi dari pintu geser yang terletak pada dinding selatan. Tidak ada kontribusi pencahayaan alami melalui jendela sedang yang terletak pada dinding selatan area gunting benang. Bukaan pintu geser juga tidak efektif dalam memasukkan cahaya karena lebih karena tidak digunakan sepanjang hari untuk memasukkan cahaya alami. 
Dari tabel 7, setelah dipenuhi standar minimal dimensi bukaan oleh Kepmenkes No. 1045 Tahun 2002 sebesar 1/6 dari luas lantai intensitas cahaya mengalami peningkatan sebesar $15.98 \%$ dari standar kebutuhan. Intensitas cahaya yang dihasilkan pada kondisi ideal hanya mencukupi $32.00 \%$ dari kebutuhan cahaya sebesar 500 lux untuk kegiatan area gunting benang.
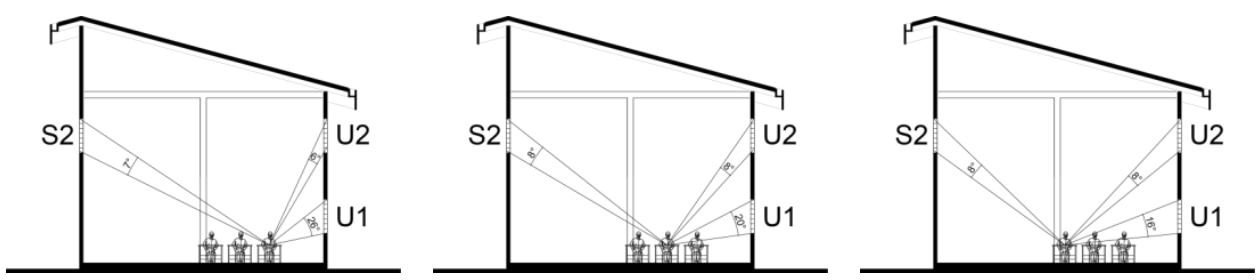

Figur 20. Distribusi Intensitas Cahaya Oleh Lubang Cahaya Area Gunting Benang

Sudut intensitas cahaya yang terbentuk dari masing-masing bukaan sebesar $7^{\circ}$ pada $S 2,26^{\circ}$ pada $\mathrm{U} 1$, dan $6^{\circ}$ pada U2. Sedangkan untuk distribusi intensitas cahaya pada meja gunting benang yang terletak di tengah, sudut intensitas cahaya yang terbentuk sebesar $8^{\circ}$ pada $\mathrm{S} 2,16^{\circ}$ pada $\mathrm{U} 1$, dan $8^{\circ}$ pada U2. Sehingga jendela sedang U1 tetap merupakan sumber intensitas tertinggi pada meja gunting benang yang berada di pinggir. Intensitas cahaya dari jendela U1 semakin berkurang pada meja gunting benang yang terletak di tengah.

Jendela tinggi tidak menghasilkan intensitas cahaya yang tinggi pada seluruh posisi meja gunting benang. Sudut distribusi yang terbentuk dari jendela tinggi, terhadap meja gunting benang yang terletak di pinggir dan di tengah, juga menunjukkan perbedaan intensitas yang tidak signifikan. Sebagian berkas cahaya yang masuk melalui jendela tinggi juga dipantulkan terlebih dahulu ke bidang dinding dan plafon.
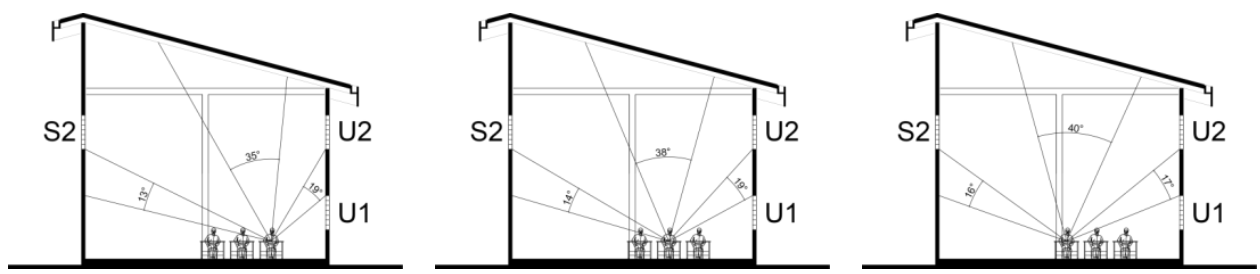

Figur 21. Distribusi Intensitas Cahaya Oleh Bidang Permukaan Area Gunting Benang

Sudut distribusi cahaya yang terbentuk pada bidang kerja bagian tengah sebesar $40^{\circ}$ pada plafon, serta $17^{\circ}$ dan $16^{\circ}$ pada dinding utara dan selatan. Semakin pinggir titik bidang kerja, semakin berkurang efektifitas refleksi material dalam mendistribusikan cahaya ke bidang kerja. Sudut distribusi intensitas cahaya terhadap bidang kerja yang terletak di pinggir berkurang menjadi $35^{\circ}$ oleh plafon, serta $13^{\circ}$ dan $19^{\circ}$ oleh dinding utara dan selatan.

Posisi bukaan jendela sedang pada sisi utara area gunting benang efektif untuk meningkatkan pencahayaan pada bidang kerja yang terletak di pinggir dengan intenitas lebih dari 2 kali lipat cahaya dari sumber lubang cahaya lainnya. Sedangkan jendela tinggi dapat meningkatkan intensitas cahaya pada seluruh bidang kerja secara merata, terutama pada meja gunting benang yang terletak di tengah. Cahaya yang masuk melalui jendela tinggi didukung oleh bidang permukaan dinding dan plafon sehingga dapat didistribusikan secara tersebar. 
Peningkatan intensitas cahaya dapat dilakukan pada kedua posisi bukaan sesuai dengan kebutuhannya masing-masing. Intensitas cahaya yang masuk melalui posisi bukaan jendela tinggi masih dapat ditingkatkan potensinya dengan opsi menambah dimensi lubang cahaya, mengganti material bukaan glass block dengan kaca bening, atau meningkatkan nilai reflektansi material dinding dan plafon. Sedangkan pada jendela sedang, peningkatan dapat dilakukan dengan opsi menambah dimensi bukaan.

\subsection{PENCAHAYAAN AREA GOSOK}

Dari hasil pengukuran langsung di lapangan, dikaitkan dengan standar rekomendasi kebutuhan pencahayaaan sesuai dengan kegiatan, diperoleh perbandingan nilai intensitas cahaya pada area gosok.
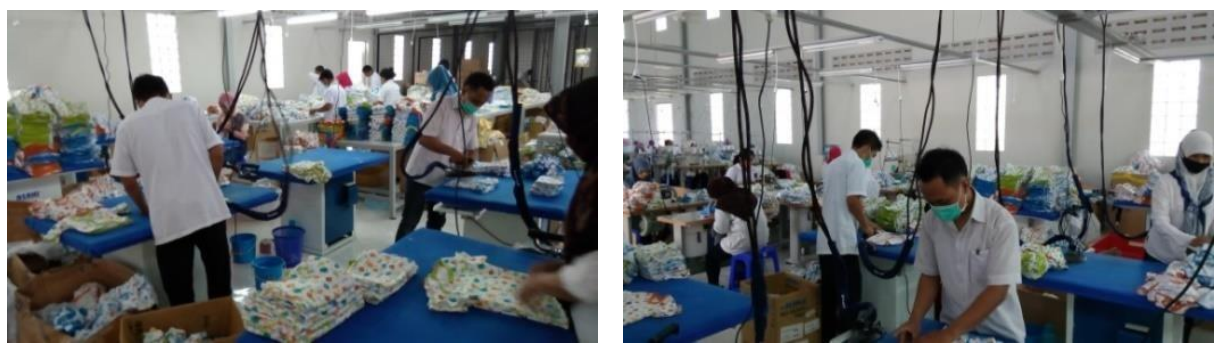

Figur 22. Kondisi Interior Area Gosok

Tabel 8. Perbandingan Hasil Pengukuran Intensitas Cahaya Area Gosok

\begin{tabular}{|c|c|c|c|}
\hline \multirow{2}{*}{ Titik Ukur } & \multicolumn{3}{|c|}{ Intensitas Cahaya (lux) } \\
\cline { 2 - 4 } & 09.00 & 12.30 & 15.30 \\
\hline D1 & 114.8 & 148.4 & 153.6 \\
\hline D2 & 102.2 & 129.5 & 131.4 \\
\hline D3 & 88.2 & 114.4 & 81.7 \\
\hline D4 & 85.5 & 102.3 & 83.3 \\
\hline Nilai Median & 95.20 & 121.95 & 106.55 \\
\hline \% Terhadap Standar 200 lux & $47.60 \%$ & $60.98 \%$ & $53.27 \%$ \\
\hline
\end{tabular}

Pada area gosok, intensitas cahaya hanya memenuhi $47 \%$ - 60\% kebutuhan intensitas pencahayaan sebesar 200 lux. Konfigurasi meja gosok terletak pada bagian tengah hingga utara bangunan, sedangkan bagian selatan area gosok digunakan sebagai sirkulasi dari pintu geser pada bidang dinding selatan. Area gosok berbatasan langsung dengan pintu geser dan ruang boiler tertutup sehingga tidak ada kontribusi pencahayaan alami melalui jendela rendah yang terletak pada dinding selatan area gosok. 
Tabel 9. Perbandingan Hasil Simulasi Kondisi Eksisting dan Kondisi Ideal Area Gosok

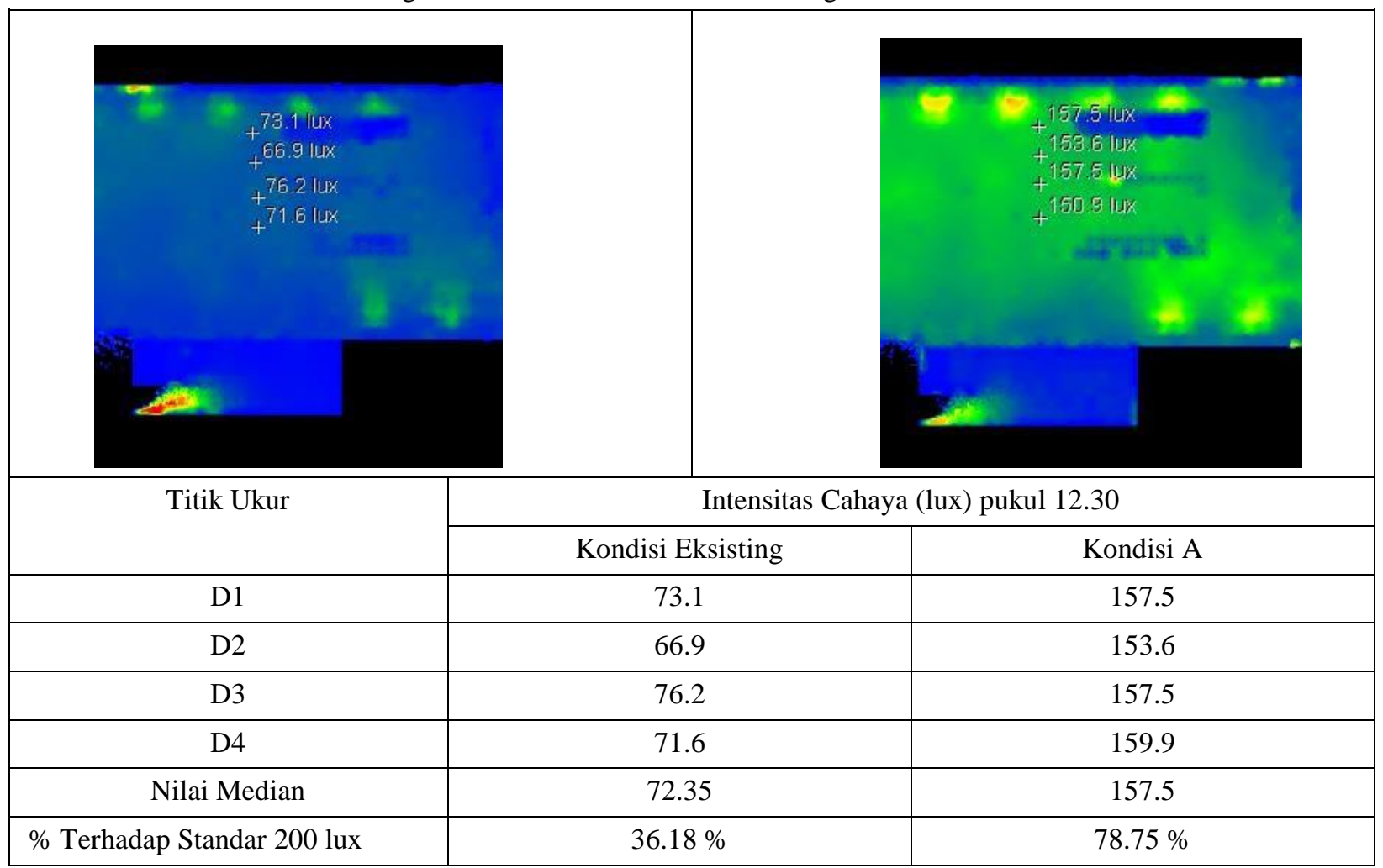

Dari tabel 9, intensitas cahaya area gosok mengalami peningkatan sebesar $42.57 \%$ kebutuhan intensitas cahaya, setelah dipenuhi standar minimal dimensi bukaan oleh Kepmenkes No. 1045 Tahun 2002, sebesar 1/6 dari luas lantai. Intensitas sebesar 157.5 lux tersebut sudah dapat memenuhi sebagian besar kebutuhan intensitas untuk kegiatan gosok, yaitu sebesar $78.75 \%$ dari kebutuhan intensitas sebesar 200 lux, sehingga optimalisasi variabel dimensi bukaan cukup efektif untuk meningkatkan distribusi cahaya pada area gosok.
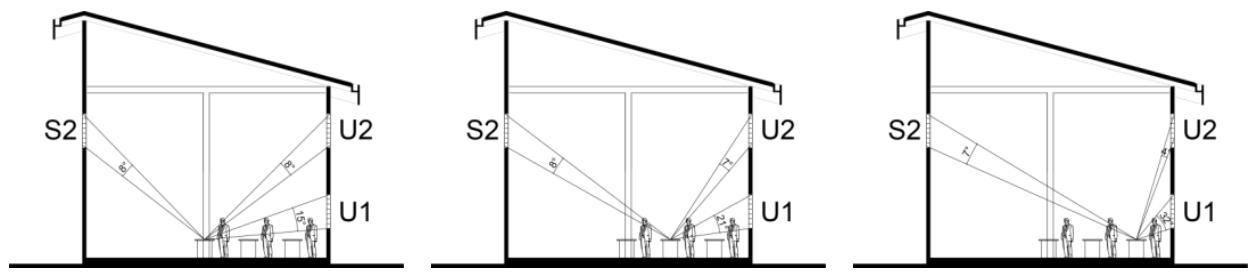

Figur 23. Distribusi Intensitas Cahaya Oleh Lubang Cahaya Area Gosok

Sudut intensitas cahaya yang terbentuk pada posisi meja gosok yang terletak di pinggir sebesar $7^{\circ}$ pada $\mathrm{S} 2,32^{\circ}$ pada U1, dan $4^{\circ}$ pada U2. Sedangkan sudut intensitas cahaya yang terbentuk pada posisi meja gosok bagian tengah lebar bangunan sebesar $8^{\circ}$ pada $S 2,15^{\circ}$ pada $U 1$, dan $8^{\circ}$ pada U2. Namun sudut distribusi intensitas cahaya oleh lubang cahaya U1 terhalang oleh pengguna yang membelakangi bukaan, sehingga jendela sedang tidak efektif digunakan sebagai pencahayaan area gosok. Posisi pengguna terhadap lubang cahaya berpotensi menghasilkan 
gangguan silau atau kontras yang berlebih karena timbul bayang-bayang pengguna pada bidang kerja.

Jendela tinggi lebih baik untuk memasukkan cahaya ke bidang kerja. Meskipun sudut intensitas yang terbentuk hanya $7^{\circ}-8^{\circ}$, sebagian berkas cahaya yang masuk melalui jendela tinggi dipantulkan terlebih dahulu ke bidang dinding dan plafon yang berperan sebagai sumber cahaya tambahan ke meja gosok.
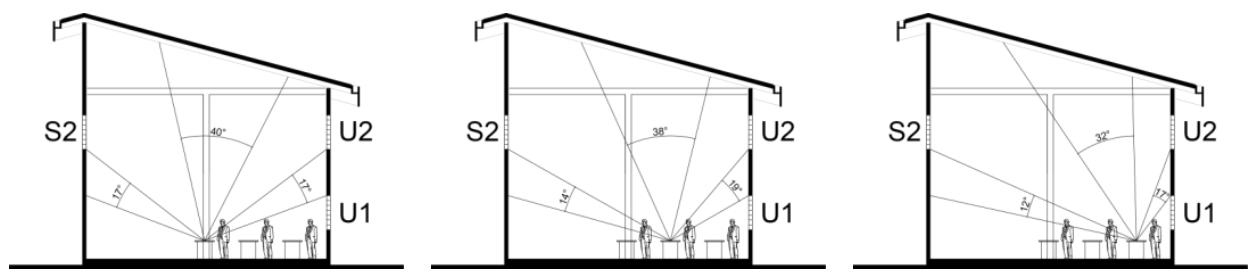

Figur 24. Distribusi Intensitas Cahaya Oleh Bidang Permukaan Area Gosok

Refleksi dari dinding utara dan selatan kurang efektif untuk meningkatkan pencahayaan pada bidang kerja karena sudut distribusi cahaya terhalang oleh posisi pengguna pada area gosok. Sehingga bidang plafon merupakan bidang permukaan area gosok yang paling berkontribusi untuk meningkatkan pencahayaan pada meja gosok.

Dari hasil penjabaran tersebut, setelah dikaitkan dengan konfigurasi meja gosok sebagai bidang kerja, posisi bukaan jendela sedang tidak digunakan untuk memasukkan cahaya alami ke meja gosok. Sebaliknya, posisi bukaan jendela tinggi berkontribusi besar untuk meningkatkan intensitas cahaya pada bidang kerja sekaligus membentuk general lighting pada area gosok.

Intensitas cahaya yang masuk melalui posisi bukaan jendela tinggi masih dapat ditingkatkan potensinya dengan opsi menambah dimensi lubang cahaya atau mengganti material bukaan glass block dengan kaca bening. Usaha untuk meningkatkan intensitas cahaya pada area gosok juga dapat dilakukan dengan meningkatkan tingkat reflektansi material plafon.

\section{PENUTUP}

Kondisi pencahayaan pada masing-masing tahap produksi CV Evergreen Buana Prima Sandang, dari area potong, area obras, area gunting benang, dan area gosok belum memenuhi standar intensitas cahaya yang direkomendasikan. Kurangnya intensitas cahaya tersebut dipengaruhi oleh dimensi, posisi, dan material lubang cahaya yang didesain seragam pada kebutuhan yang bervariasi.

Dalam simulasi kondisi ideal sesuai rekomendasi dimensi lubang cahaya oleh Kepmenkes No. 1045 Tahun 2002, seluruh lubang cahaya glass block juga tetap tidak dapat memenuhi setiap kebutuhan intensitas cahaya pada setiap area tahapan produksi pabrik. Artinya standar Kepmenkes tersebut tidak dapat digunakan untuk memenuhi kebutuhan pencahayaan, pada kondisi penggunaan material bukaan glass block.

Material glass block mengurangi intensitas cahaya yang didistribusikan karena sifat material sebagai diffuser. Cahaya yang melewati glass block didistribusikan tersebar jauh ke dalam ruang karena komponen prisma kaca sferis pada glass block merefraksikan cahaya ke arah atas. 
Perbandingan dimensi bukaan terhadap luas ruang juga sangat kecil sehingga mengurangi distribusi intensitas cahaya ke dalam ruang. Namun faktor dimensi bukan satusatunya yang mempengaruh kurangnya intensitas, karena simulasi pada dimensi ideal pun tidak dapat memenuhi kebutuhan intensitas cahaya pada ruang.

Posisi bukaan jendela sedang mendisitribusikan cahaya dengan intensitas yang terpusat hanya pada bidang kerja area produksi yang terletak di sisi pinggir saja. Namun tidak seluruh posisi bukaan jendela sedang efektif untuk memasukkan cahaya ke bidang kerja, sehingga harus dikaitkan dengan konfigurasi meja kerja pada masing-masing area produksi.Posisi bukaan jendela tinggi mendistribusikan cahaya jauh ke dalam ruang dan lebih efektif untuk menyebarkan intensitas cahaya secara merata ke dalam ruang. Jendela tinggi juga menghasilkan potensi bagi bidang permukaan dinding dan plafon pada area produksi untuk turut berkontribusi meningkatkan intensitas cahaya pada ruang.

Kesimpulan dari penelitian ini adalah masing-masing lubang cahaya pada setiap area produksi dapat ditentukan strategi khusus untuk dapat meningkatkan distribusi intensitas pada bidang kerja yang berbeda-beda. Pada area potong dan area gosok, intensitas cahaya lebih efektif ditingkatkan melalui penambahan dimensi lubang cahaya, penggantian material pada bukaan tinggi, dan peningkatan tingkat reflektansi material. Pada area obras dan area gunting benang, intensitas cahaya dapat ditingkatkan baik melalui jendela tinggi dan sedang. Peningkatan melalui jendela sedang dapat dilakukan dengan memperbesar dimensi bukaan saja.

\section{DAFTAR PUSTAKA}

Darrington, Paul. 1976. "Factories” Planning: Building for Habitation, Commerce, and Industry. Newnes-Butterworths.

Gunawan, ryani. (2011). Simulasi Rancangan Bukaaan Pencahayaan Cahaya Matahari Langsung. Research Report - Engineering Science, Volume 1, 2011.

Indonesia. 2002. Keputusan Menteri Kesehatan No. 1045 Tahun 2002 tentang Persyaratan Kesehatan Lingkungan Kerja Perkantoran dan Industri. Jakarta:

Kementerian/Sekretariat Negara Republik Indonesia. [Kputusan Menteri]

Kingsbury, howard f. 1957. "Glass Block." Windows and Glass in the Exterior of Buildings.

National Academy of Sciences Publication 478. Washington, D.C.: 1957, 86-92.

Lam, william m.c. 1992. Perception and Lighting as Formgivers for Architecture. New York: Van Nostrand Reinhold.

Lechner, robert. 2015. Heating, Cooling, Lighting: Sustainable Design Methods for Architects Fourth Edition. New Jersey: John Wiley \& Sons, Inc.

Lyons, stanley. 1992. Lighting for Industry and Security: A Handbook for Providers and Users of Lighting. London: Butterworth-Heinemann.

Mcneil, andy. 2015. Putting Radiance to Work Modelling Glass Block. Radiance Workshop.

Neufert, ernst. 2000. Neufert's architect data third edition. Wiley-blackwell.

Phillips, derek. 1964. Lighting in architectural design. New york: mcgraw hill. 
Szokolay, s.v., arvind krishan, nick baker, dan simon yannas. 2001. Architecture: a design handbook for energy efficient buildding. New i hill publishing co.ltd.

Indonesia. 2001. Sni 03-2396-2001 tentang tata cara perancangan sistem pencahayaan alami pada bangunan gedung. Badan standarisasi nasional.

Indonesia. 2001. Sni 03-6575-2001 tentang tata cara perancangan sistem pencahayaan buatan pada bangunan gedung. Badan standarisasi nasional.

Vos, johannes j. 2003. Reflections on glare. Lighting research and technology, volume 35, no. 2. Netherlands: 2003, 163-175. 